\title{
Easing the journey back home
}

\section{Thomas Mayer: A repatriation award contributed significantly to my decision to go back to Germany.}

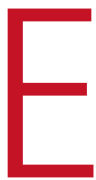

ach year, many young European scientists start postdoctoral work in the United States. But on completion, they can face difficulties in securing a position back home. Repatriated scientists, even when highly qualified, often lose out to better-connected internal candidates if they don't have strong backing within the department.

Last year, Spain launched a programme that has already brought a sizeable number of its scientists back (see Nature 413, 556; 2001). Among other countries that send a large number of scientists abroad with stipends are the United Kingdom, Germany and France. Granting agencies in each country have come up with different approaches to ease the transition.

Frank Gannon, executive director of the European Molecular Biology Organization (EMBO), sees these programmes as a start, and a "component of lowering barriers". Improving each country's quality of science is a long-term way to retain scientific talent, he adds.

Enric Banda, secretary general of the European Science Foundation, agrees that the scientific environment is most important. He would like to see more independent positions that let young scientists run their own projects. "Europe has certainly identified this issue," he says, "but actions are slow, let alone results."

\section{WELLCOME HOME}

At the start of this year, Britain's Wellcome Trust awarded the first of its International Research Fellowships (IRFs), which provide up to four years of support. After two to three years outside Britain or Ireland, holders receive up to two more years' repatriation support.

Bruce Turnbull, a chemist at the University of Leeds, received the IRF's precursor award, the International Prize Travelling Research Fellowship (IPTRF). This provided funding for two years abroad plus an additional year after the return. Turnbull says that many of his European colleagues at the University of California, Los Angeles, had problems arranging jobs back home. Turnbull would have considered staying in the United States, but the repatriation funding made going home an "easy decision", he says.

Postdocs Richard Wade-Martins and Eric Miska, two current IPTRF holders in Boston, agree that this type of fellowship provides generous support, but they

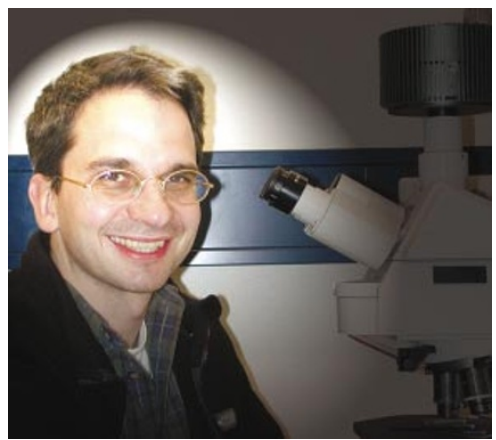

feel that two years abroad may not be enough to complete a project and get the results published. They both see the IRF's extra year as a big improvement.

\section{GERMAN APPROACH}

Germany's main grant agency, the DFG, aids postdocs with its Emmy Noether Programme. Phase one gives two years of support for a postdoctoral research project abroad; the second phase adds funding to establish a small research group back in Germany.

Cell biologist Thomas Mayer left Harvard last year to set up a lab in Germany. Mayer, now at the Max Planck Institute of Biochemistry near Munich, is glad that he did not have to seek grants to get started. Enjoying a level of independence that is unusual in his country, he says that the Emmy Noether award "contributed significantly" to his decision to return to Germany.

Emmy Noether fellow Burckhard Seelig is slightly concerned that two years may not be enough time to finish a project. So the German biochemist, like many IPTRF recipients, secured funding while at Massachusetts General Hospital and will seek an extension before going home.

\section{CNRS EFFORT}

The French national research foundation CNRS helps about 3,000 French scientists in the United States and, together with the French embassy, organizes an annual careers fair called Forum USA. According to the head of the Washington office, Dominique Martin-Rovet, the CNRS fills $15 \%$ of its vacant positions with applicants working in the United States.

Cyril Delattre, a chemical engineer at the Massachusetts Institute of Technology, attended Forum USA to get information about opportunities in France's private sector. "It's very helpful, you don't have to fly to France to talk to all the human resources managers," says Delattre. But he adds that applying for an academic post at the CNRS is more difficult. Before submitting a research proposal it is vital to visit potential labs and secure the support of the principal investigator. According to Delattre, this is no small feat if you "feel disconnected" by distance. Jan Schmollinger is a graduate student in Boston.
Web links Wellcome Trust , www.wellcome.ac.uk DFG www.dfg.de CNRS

www.enrs.fr Forum USA www.forumusa.org 